\title{
Pemilihan Resep Masakan Berdasarkan Ketersediaan Bahan Masakan dengan Metode Simple Matching Coefficient (SMC)
}

\author{
Ramadhaniati Sari ${ }^{1}$, Tursina $^{2}$, Anggi Srimurdianti Sukamto ${ }^{3}$ \\ Jurusan Informatika, Universitas Tanjungpura \\ Jl. Prof. Dr. H. Hadari Nawawi, Pontianak, Kalimantan Barat 78115 \\ ${ }^{1}$ ramadhaniati.sari@gmail.com \\ ${ }^{3}$ anggidianti@informatika.untan.ac.id \\ ${ }^{2}$ tursinalinformatika.untan.ac.id
}

\begin{abstract}
Abstrak- Resep masakan dibutuhkan sebagai suatu sarana yang dapat menuntun pada saat mempersiapkan bahanbahan masakan, cara pembuatan serta cara penyajian. Sering kali seorang pengolah makanan yang mencari resep memiliki kesulitan untuk menentukan menu apa yang akan dimasak dengan bahan masakan yang tersedia di dapur. Oleh karena itu, dibangun aplikasi berbasis website untuk memudahkan pengguna dalam melakukan pemilihan resep masakan. Banyaknya jumlah data resep masakan yang bervariasi, memungkinkan untuk diterapkan penalaran berbasis kasus atau yang dikenal dengan Case-Based Reasoning (CBR). Dalam penelitian ini , peneliti menggunakan metode Simple Matching Coefficient (SMC) untuk menghitung kemiripan (similaritas). Aplikasi ini memberikan rekomendasi resep masakan apa saja yang dapat dibuat dengan meng-input-kan bahan-bahan masakan yang tersedia dan aplikasi ini juga memberikan resep lengkapnya beserta langkah-langkah memasak. Pengujian pada hasil akhir sistem menggunakan pengujian tahapan CBR, pengujian metode Simple Matching Coefficient (SMC) dan pengujian kuesioner dengan perhitungan metode Likert's Summated Rating (LSR). Berdasarkan hasil pengujian metode Simple Matching Coefficient (SMC) dengan menggunakan 20 kasus uji, menunjukkan bahwa hasil perhitungan persentase rata-rata nilai similaritas tertinggi didapat nilai sebesar $89 \%$ sehingga sistem ini dapat memberikan rekomendasi resep masakan terbaik. Pada hasil pengujian dengan metode LSR menunjukkan skor 1343 yang artinya, hasil pengujian kuesioner menandakan responden menilai aplikasi sangat positif dan dinilai berhasil.
\end{abstract}

Kata kunci- Resep masakan, Case-Based Reasoning, Simple Matching Coefficient, rekomendasi, Likert's Summated Rating.

\section{PENDAhULUAN}

Memasak adalah suatu kegiatan yang dilakukan oleh seseorang dengan mengolah bahan makanan melalui proses penerapan panas dengan tujuan tertentu [1]. Dalam memasak, terdapat sedikit perbedaan pada jumlah takaran bahan dan bumbu serta cara pengolahannya sehingga diperlukan resep masakan untuk dijadikan acuan dalam memasak. Resep masakan adalah takaran yang digunakan untuk mengolah bahan makanan yang telah teruji ke akuratannya [2]. Kumpulan resep masakan yang tersedia biasanya berasal dari buku resep, koran, majalah, maupun televisi. Hal tersebut dinilai kurang efisien dalam penggolongan menurut kategori jenis masakan, sehingga menyulitkan dalam hal pencarian dan pengarsipan koleksi resep masakan.

Sering kali seorang pengolah makanan seperti ibu rumah tangga yang mencari resep memiliki kesulitan untuk menentukan menu apa yang akan dimasak dengan bahan masakan yang tersedia di dapur. Seiring dengan perkembangan teknologi, maka pencarian resep masakan akan lebih mudah dilakukan melalui website. Oleh karena itu akan dibangun aplikasi berbasis website untuk memudahkan user dalam melakukan pemilihan resep masakan. Sehingga dapat memberikan rekomendasi resep masakan apa saja yang dapat dibuat dengan meng-inputkan bahan-bahan masakan apa saja yang tersedia di dapur user.

Banyaknya jumlah data resep masakan yang bervariasi, yang didapat dari berbagai sumber buku resep masakan dan situs di internet, maka memungkinkan untuk menerapkan penalaran berbasis kasus atau yang dikenal dengan Case-Based Reasoning (CBR). Sumber pengetahuan utama sistem CBR adalah berdasarkan kasus-kasus yang telah ada atau yang telah tersimpan didalam basis kasus [3]. Metode yang digunakan dalam menghitung kemiripan (similaritas) adalah Simple Matching Coefficient (SMC). Metode SMC ini merupakan salah satu cara perhitungan similaritas untuk data biner [4].

Beberapa penelitian yang menggunakan konsep penalaran berbasis kasus dan mengenai resep masakan yang telah dilakukan antara lain, penelitian yang dilakukan Salsabella (2014) melakukan penelitian dengan judul "Sistem Pendukung Keputusan Penentuan Resep Masakan Berdasarkan Ketersediaan Bahan Makanan 
Menggunakan Metode Simple Additive Weighting (SAW) Berbasis Web" [5]. Hasil penelitiannya yaitu berupa aplikasi yang dapat digunakan untuk mencari resep masakan secara online. Pengguna akan memasukkan bahan makanan, bumbu masakan, waktu memasak, jenis masakan dan cara memasak serta memasukkan tingkat kesulitan resep masakan yang diinginkan pengguna(pemula / beginner, menengah / intermediate, ahli / expert). Dari hasil pemasukan data tersebut, aplikasi akan menentukan resep masakan yang cocok sesuai keinginan pengguna. Kriteria yang dijadikan sebagai bahan perhitungan pada proses perankingan yaitu bahan makanan, bumbu masakan, tingkat kesulitan, waktu memasak, jenis masakan, dan cara memasak.

Tursina (2014) melakukan penelitian yang menggunakan Penalaran Berbasis Kasus atau disebut dengan Case Based Reasoning (CBR) dengan judul "Case Based Reasoning Untuk Menentukan Daerah Berpotensi Demam Berdarah (Studi Kasus Kota Pontianak)" [6]. Hasil penelitiannya yaitu berupa sebuah sistem yang dapat menentukan daerah berpotensi demam berdarah menggunakan metode Simple Matching Coefficient (SMC) untuk menghitung kemiripan (similaritas), sehingga menghasilkan keluaran berupa status tingkat kerawanan : tidak rawan, rawan, dan sangat rawan. Fitur-fitur yang digunakan yaitu curah hujan, suhu udara, kelembapan udara, kepadatan penduduk, jumlah sarana kesehatan, frekuensi DBD bulanan perkelurahan, status daerah : tidak rawan, rawan, dan sangat rawan. Fitur-fitur tersebut yang akan dijadikan input sistem.

Rani (2016) melakukan penelitian yang menggunakan Case Based Reasoning (CBR) dengan metode Nearest Neighbor untuk menghitung kemiripan atau similaritas dengan judul "Penerapan Metode Case Based Reasoning Pada Pengembang Aplikasi Recipe Recommendation Berbasis Android" [7]. Hasil penelitianya yaitu berupa sebuah sistem yang dapat memberikan rekomendasi masakan apa saja yang dapat dibuat dengan menginput bahan-bahan apa saja yang tersedia dan aplikasi ini juga memberikan resep lengkapnya beserta langkah-langkah memasak dan cara penyajiannya. Fitur yang digunakan berupa bahan-bahan makanan.

Faizal (2016) melakukan penelitian menggunakan Case Based Reasoning (CBR) dengan judul "Case Based Reasoning Diagnosis Penyakit Cardiovascular dengan Metode Simple Matching Coefficient Similarity" [8]. Hasil penelitiannya adalah sistem yang memiliki kemampuan untuk mendiagnosa penyakit cardiovascular berdasarkan kemiripan (similaritas) pada kasus-kasus terdahulu menggunakan metode Simple Matching Coefficient (SMC). Fitur-fitur yang digunakan yaitu gejala dan faktor resiko pada pasien.

Annisa (2017) melakukan penelitian menggunakan Case Based Reasoning (CBR) dengan judul "Diagnosis Kerusakan Komputer Menggunakan Metode Similarity Jaccard Coefficient" [9]. Fitur yang digunakan dalam mendiagnosis dalam kerusakan komputer adalah gejala kerusakan. Hasil penelitiannya adalah sistem yang memiliki kemampuan mendiagnosis kerusakan hardware komputer dengan menggunakan metode Similarity Jaccard Coefficient.

\section{METODOLOGI PENELITIAN}

\section{A. Case Based Reasoning (CBR)}

Case Based Reasoning (CBR) adalah penalaran yang bertujuan untuk menyelesaikan permasalahan baru dengan cara mengadaptasi solusi-solusi yang terdapat pada kasuskasus sebelumnya yang mempunyai permasalahan yang mirip dengan kasus baru[10].

Terdapat empat langkah proses pada metode CaseBased Reasoning, [11]:

1. Retrieve yaitu mengambil kembali permasalahan yang sama. Pada langkah ini dilakukan proses pencarian atau kalkulasi dari kasus-kasus yang memiliki kesamaan.

2. Reuse yaitu menggunakan kembali informasi dan pengetahuan dalam kasus tersebut untuk mengatasi masalah baru. Pada langkah ini dicari solusi dari kasus serupa pada kondisi sebelumnya untuk permasalahan baru.

3. Revise yaitu meninjau kembali solusi yang diberikan. Pada langkah ini dicari solusi dari kasus serupa pada kondisi sebelumnya untuk permasalahan yang terjadi kemudian.

4. Retain yaitu proses yang menyimpan pengalaman untuk memecahkan masalah yang akan datang ke dalam basis kasus. Permasalahan yang akan diselesaikan adalah permasalahan yang memiliki kesamaan dengannya. Pada tahap ini terjadi suatu proses penggabungan dari solusi kasus yang baru ke knowledge yang telah ada.

Siklus Case-Based Reasoning dapat dilihat pada Gambar. 1.

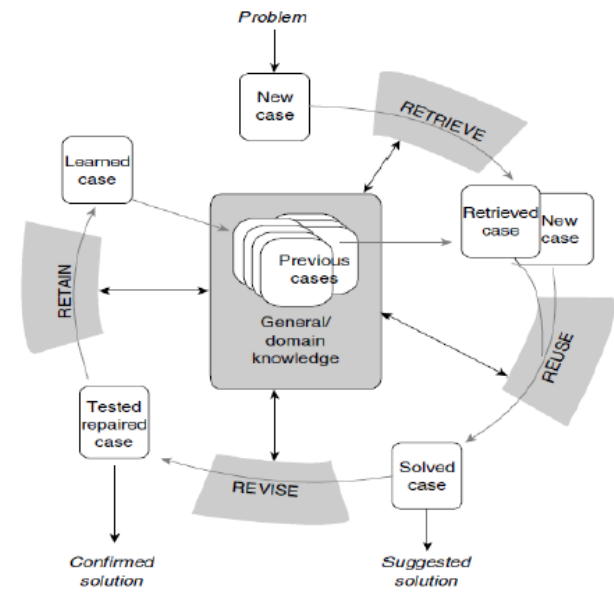

Gambar. 1 Siklus Case-Based Reasoning

Berdasarkan tahapan yang ada dalam CBR, diperlukan dua langkah utama dalam menentukan solusi, yaitu[12]:

- Membangun basis kasus, yang digunakan sebagai tempat penyimpanan. 
- Menentukan fungsi kemiripan (similarity), langkah ini digunakan untuk mengenali kesamaan atau kemiripan antara kasus-kasus yang tersimpan dalam basis kasus dengan kasus yang baru.

\section{B. Similarity Simple Matching Coefficient (SMC)}

Similarity Simple Matching Coefficient (SMC), merupakan salah satu metode perhitungan yang digunakan untuk menghitung tingkat similaritas dua buah objek yang bersifat biner[13].

Pada penalaran Cased Based Reasoning, SMC digunakan untuk membandingkan fitur-fitur yang terdapat pada basis kasus dengan fitur yang terdapat pada kasus baru.

Formula yang digunakan SMC untuk menghitung similarity, antara dua objek $\mathrm{X}$ dan $\mathrm{Y}$ adalah sebagai berikut:

\section{Similarity Simple Matching Coefficient (SMC)}

$$
\begin{aligned}
& \operatorname{SMC}(X, Y)=\frac{\mathrm{M} 11+\mathrm{M} 00}{\mathrm{M} 10+\mathrm{M} 01+\mathrm{M} 11+\mathrm{M} 00} \\
& \text { Dimana : }=\text { Kasus Lama } \\
& \mathrm{X} \quad=\text { Kasus Baru } \\
& \begin{array}{l}
\text { Y } \quad \text { Jumlah Atribut dimana } \mathrm{X}=1 \text { dan } \mathrm{Y}=1 \\
\text { M11 = Jumlah Atribut dimana } \mathrm{X}=1 \text { dan } \mathrm{Y}=0 \\
\text { M01 = Jumlah Atribut dimana } \mathrm{X}=0 \text { dan } \mathrm{Y}=1 \\
\text { M00 = Jumlah Atribut dimana } \mathrm{X}=0 \text { dan } \mathrm{Y}=0
\end{array}
\end{aligned}
$$

Kasus baru dikatakan similar (mirip) $100 \%$ dengan kasus yang lama apabila nilai similaritas dari $\operatorname{SMC}(\mathrm{X}, \mathrm{Y})$ sama dengan 1, sedangkan tidak similar apabila nilai $\mathrm{SMC}(\mathrm{X}, \mathrm{Y})$ sama dengan 0 .

\section{Pengujian Tahapan Case Based Reasoning (CBR)}

Komponen penyelesaian masalah CBR memiliki dua bagian utama, yaitu case retriever dan case reasoner. Case retriever bertugas untuk mencari masalah-masalah yang mirip dengan masalah yang dimasukkan pengguna didalam basis pengetahuan (case base), sementara case reasoner bertugas untuk mencari solusi masalah pengguna dengan melihat atau menyesuaikan solusi masalah yang ditemukan case retriever. Dalam eksekusinya, ada empat tahapan dalam proses CBR yaitu Retrieve, Reuse, Revise dan Retain [14].

Pengujian tahapan Case Based Reasoning (CBR) dilakukan dengan menghitung nilai similaritas oleh sistem menggunakan 20 kasus uji (kasus baru) terhadap kasus lama (basis kasus) yang data hasil perhitungan similaritas tersebut akan dirangkum pada sebuah tabel. Tabel pengujian tersebut terdiri dari 2 kolom, yaitu kolom kasus berisi kasus yang akan dilakukan pengujian terhadap sistem, dan kolom similaritas tertinggi yang berisi nilai similaritas tertinggi kasus baru terhadap kasus lama. Hasil pengujian dapat dilihat pada tabel 2.

\section{Pengujian Kuesioner}

Kuesioner merupakan teknik pengumpulan data dengan cara memberi seperangkat pertanyaan atau pernyataan tertulis kepada responden untuk menjawabnya [15].

Kuesioner berisi beberapa pertanyaan yang dikelompokkan menjadi 3 aspek yang digunakan dalam pengujian aplikasi tersebut, yaitu aspek rekayasa perangkat lunak, aspek fungsionalitas, dan aspek komunikasi visual.

Data yang diperoleh dari hasil pengujian dengan kuesioner kemudian diukur dengan metode Likert's Summated Rating (LSR)

1. Jumlah skor untuk setiap responden:

- Skor Maksimal = 50 (5 x 10 item)

- Skor Minimal = 10 (1 x 10 item $)$

- Skor Median = 30 (3 $\times 10$ item $)$

- Skor Kuartil I = 20 (2 x 10 item $)$

- Skor Kuartil III = 40 (4 x 10 item)

2. Jumlah skor untuk seluruh responden

- Maksimal $=1500(30 \times 50)$

- Minimal = $300(30 \times 10)$

- Median $=900(30 \times 30)$

- Kuartil I = $600(30 \times 20)$

- Kuartil III = $1200(30 \times 40)$

\section{PERANCANGAN SISTEM}

\section{A. Perancangan Arsitektur Sistem Pemilihan Resep Masakan}

Desain arsitektur sistem pemilihan resep masakan dapat dilihat pada Gambar. 2.

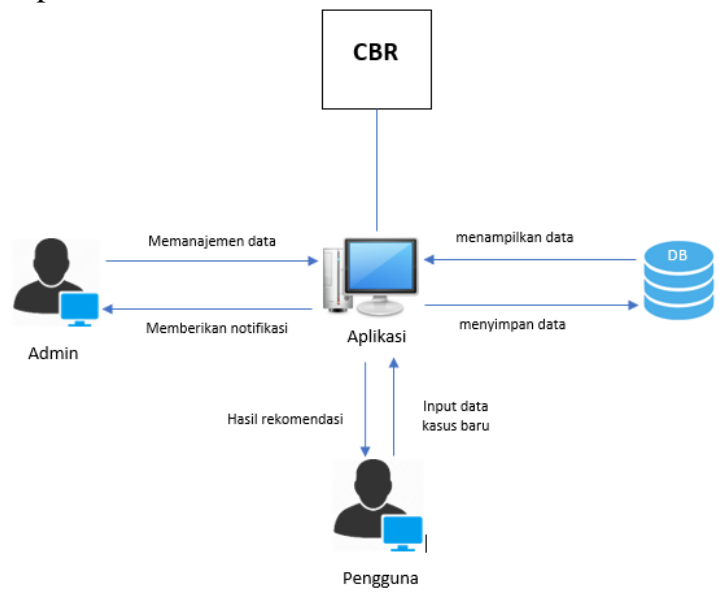

Gambar. 2 Arsitektur Sistem Pemilihan Resep Masakan

Pada Gambar 2 di dalam aplikasi terdapat proses 4R dari metode Case Based Reasoning (CBR) yaitu proses retrieve, reuse, revise, dan retain. Pengguna melakukan interaksi dengan meng-input-kan data kasus baru ke dalam aplikasi dan aplikasi akan memberikan hasil rekomendasi dari kasus yang paling mirip dengan kasus baru tersebut. Interaksi antara database dengan aplikasi terjadi saat admin melakukan manajemen data yang terdapat di aplikasi. 


\section{B. Perancangan Basis Kasus}

TABEL 1

FITUR PADA APLIKASI

\begin{tabular}{|c|l|l|l|}
\hline No & \multicolumn{1}{|c|}{ Kode } & \multicolumn{1}{|c|}{ Kategori } & \multicolumn{1}{|c|}{ Fitur } \\
\hline 1 & BAK01 & Kering & Air Kelapa \\
\hline 2 & BAK02 & Kering & Tepung Terigu \\
\hline 3 & BAK03 & Kering & Kacang Tanah \\
\hline 4 & BAK04 & Kering & Jeruk Limau \\
\hline
\end{tabular}

Berdasarkan 40 data resep masakan nusantara yang telah dikumpulkan untuk disimpan di basis kasus, data tersebut di analisis sehingga mendapatkan 55 fitur yang dibutuhkan sebagai pilihan kepada pengguna dalam menentukan rekomendasi resep masakan. Masing-masing fitur tersebut memiliki kode sesuai dengan kategori bahan dan bumbu dimana kategori tersebut terdiri dari bahan kering, bumbu kering, bahan basah, bumbu basah, bahan kering basah dan bumbu kering basah.

\section{Perancangan Diagram Alir Sistem Pemilihan Resep Masakan}

Desain diagram alir sistem pemilihan resep masakan dapat dilihat pada Gambar. 3.

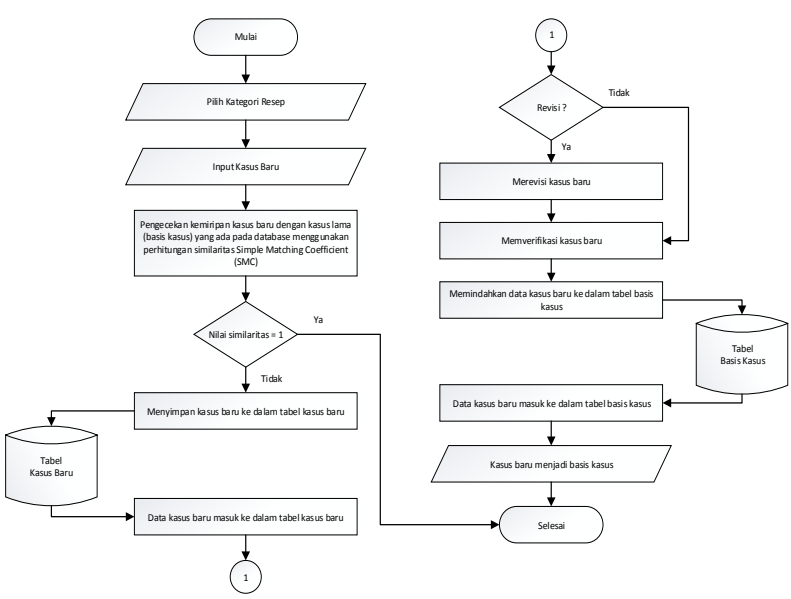

Gambar. 3 Diagram Alir Sistem Pemilihan Resep Masakan

Diagram alir sistem pemilihan resep masakan pada Gambar 3 dimulai dengan pilih kategori resep, kemudian input kasus baru. Sistem melakukan perbandingan kasus baru dengan kasus lama (basis kasus) yang tersimpan di dalam database. Proses perbandingan ini akan menghasilkan nilai similaritas yang dihitung dengan metode Simple Matching Coefficient. Jika nilai similaritas sama dengan 1, maka proses selesai. Jika nilai similaritas tidak sama dengan 1, maka kasus baru akan disimpan ke dalam tabel kasus baru. Tabel kasus baru menyimpan seluruh data kasus baru yang telah di-input-kan ke dalam sistem yang mana data tersebut dapat diolah oleh admin. Admin dapat merevisi dan me-retain data kasus baru agar dapat menjadi basis kasus. Basis kasus akan digunakan sistem sebagai acuan solusi atas kasus baru lainnya. 


\section{ANALISIS HASIL}

\section{A. Hasil Perancangan Sistem}

Gambar 4 merupakan halaman saat pengunjung memilih bahan dan bumbu masakan kering.

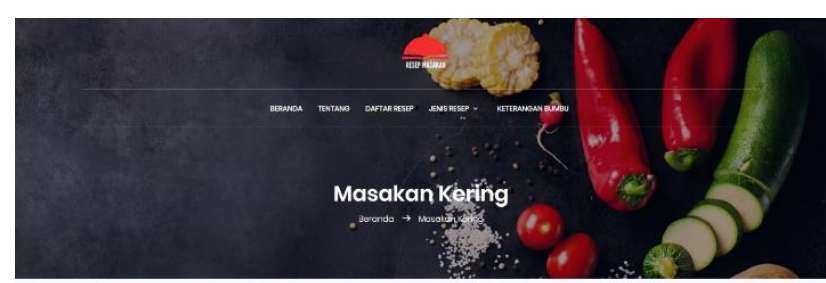

Pilih Bahan dan Bumbu
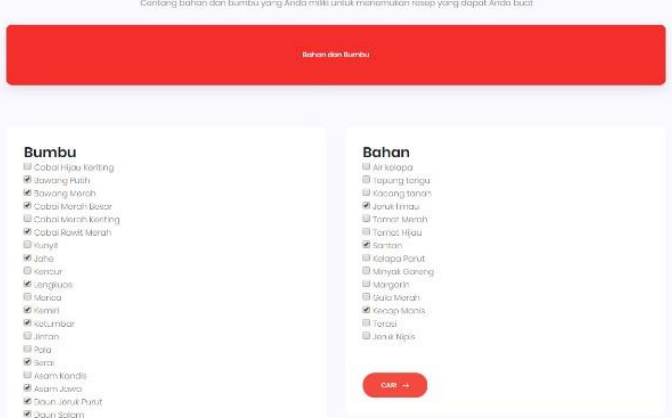

Gambar 4. Tampilan Halaman Masakan Kering

\section{B. Hasil Pengujian}

1. Pengujian Tahapan Case Based Reasoning (CBR)

- Pengujian Tahapan Retrieve adalah untuk menelusuri dan mendapatkan kasus-kasus yang mirip dalam basis kasus dengan kasus baru.

Berikut proses didalam tahapan retrieve:

Melakukan input data bahan bumbu dan melakukan pengecekan data terhadap basis kasus. Gambar 5 merupakan proses input data bahan dan bumbu.
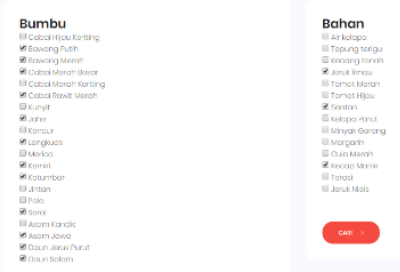

Gambar 5. Tampilan Menu Input Data Bahan Bumbu

Mencari tingkat kemiripan antara kasus uji (kasus baru) dengan kasus-kasus yang terdapat didalam basis kasus pada Gambar 6.

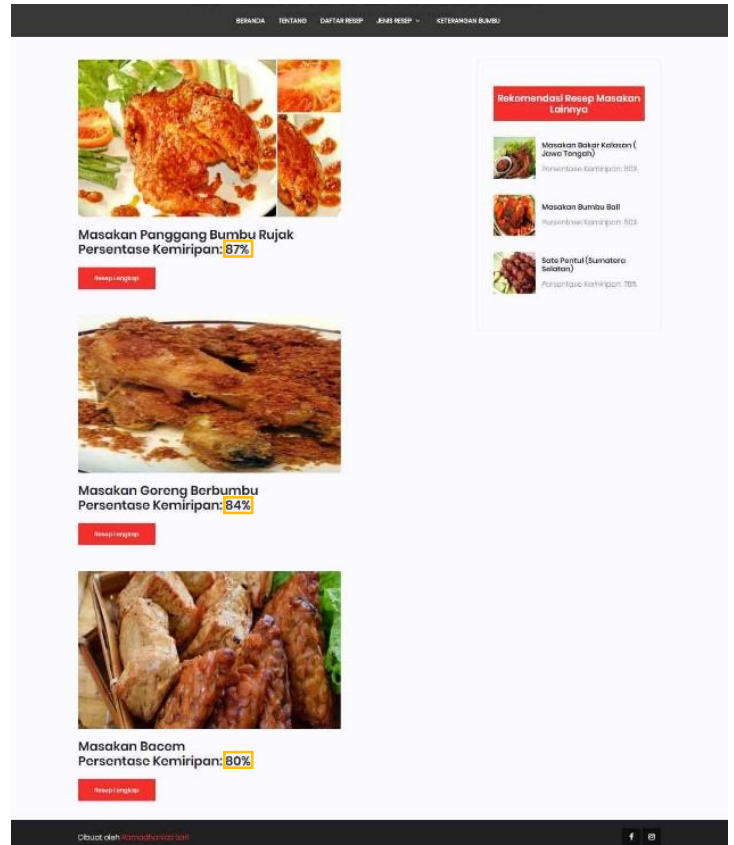

Gambar 6. Tampilan Halaman Hasil Rekomendasi Resep Masakan Dengan Tingkat Kemiripan Kasus Baru Dengan Kasus Lama Dengan Nilai Tertinggi

- Pengujian Tahapan Reuse adalah menggunakan kembali kasus-kasus yang ada dan dicoba untuk menyelesaikan suatu permasalahan baru seperti yang ditunjukkan pada Gambar 7.

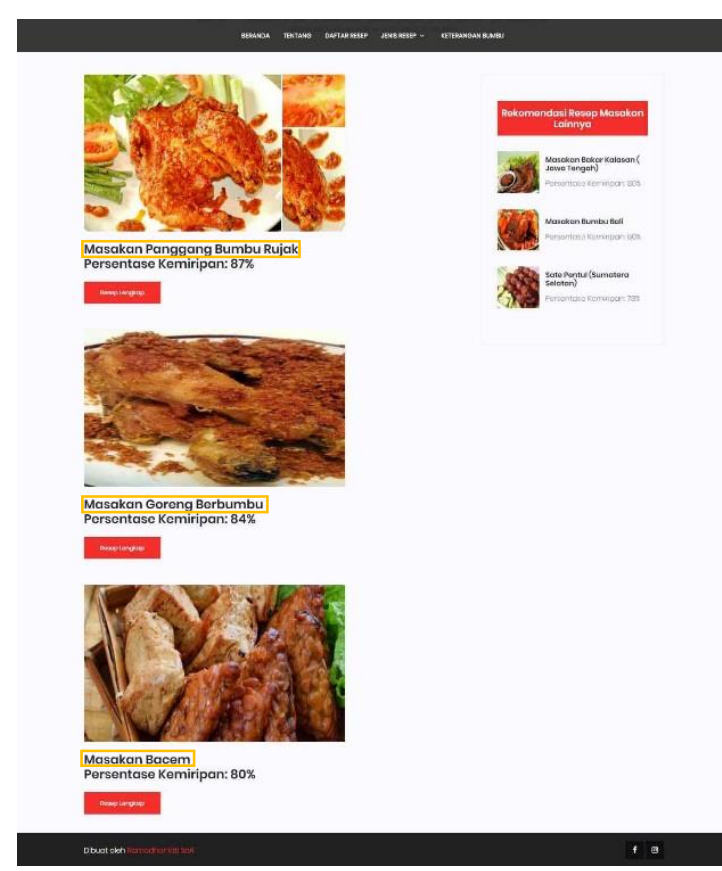

Gambar 7. Kasus Lama Yang Digunakan Sebagai Solusi

- Pengujian tahapan revise dilakukan dengan meninjau kembali untuk perbaikan data resep masakan ditunjukkan pada Gambar 8. 


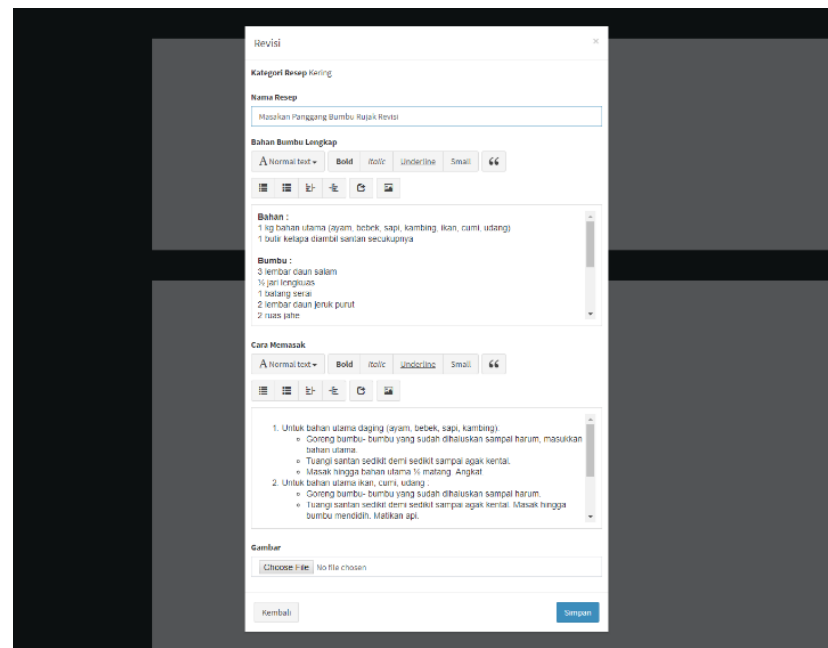

Gambar 8. Tampilan Form Revisi Kasus Baru

- Pengujian Tahapan Retain dilakukan dengan memindahkan data kasus baru ke basis kasus ditunjukkan pada Gambar 9.
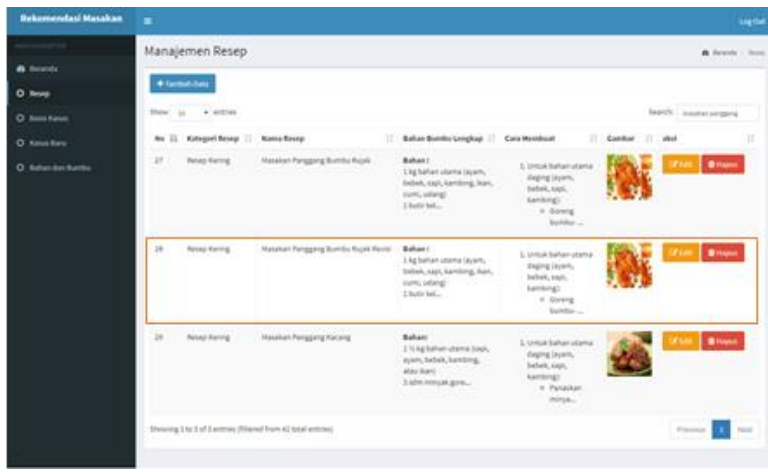

Gambar 9. Tampilan Tahapan Retain

Hasil Pengujian Metode Simple Matching Coefficient dapat dilihat pada Tabel 2. Kasus 1 pada Tabel 2 memiliki nilai similaritas tertinggi sebesar 0,87 dengan perhitungan sebagai berikut:

Berikut merupakan perhitungan kasus 1 menggunakan metode Similarity Simple Matching Coefficient (SMC) dengan kasus yang terdapat di basis kasus:

$\mathrm{M}_{11}=10, \mathrm{M}_{10}=2, \mathrm{M}_{01}=5, \mathrm{M}_{00}=38$

Maka,

$S M C(X, Y)=\frac{10+38}{2+5+10+38}=\frac{48}{55}=0,87$

Berdasarkan nilai rata-rata pada Tabel 2, didapat nilai persentase rata-rata similaritas tertinggi terhadap kasus uji sebesar $89 \%$ yang digunakan untuk mengetahui keberhasilan sistem.
TABEL 2

PERHITUNGAN RATA-RATA NILAI SIMILARITAS TERTINGG PADA KASUS UJI

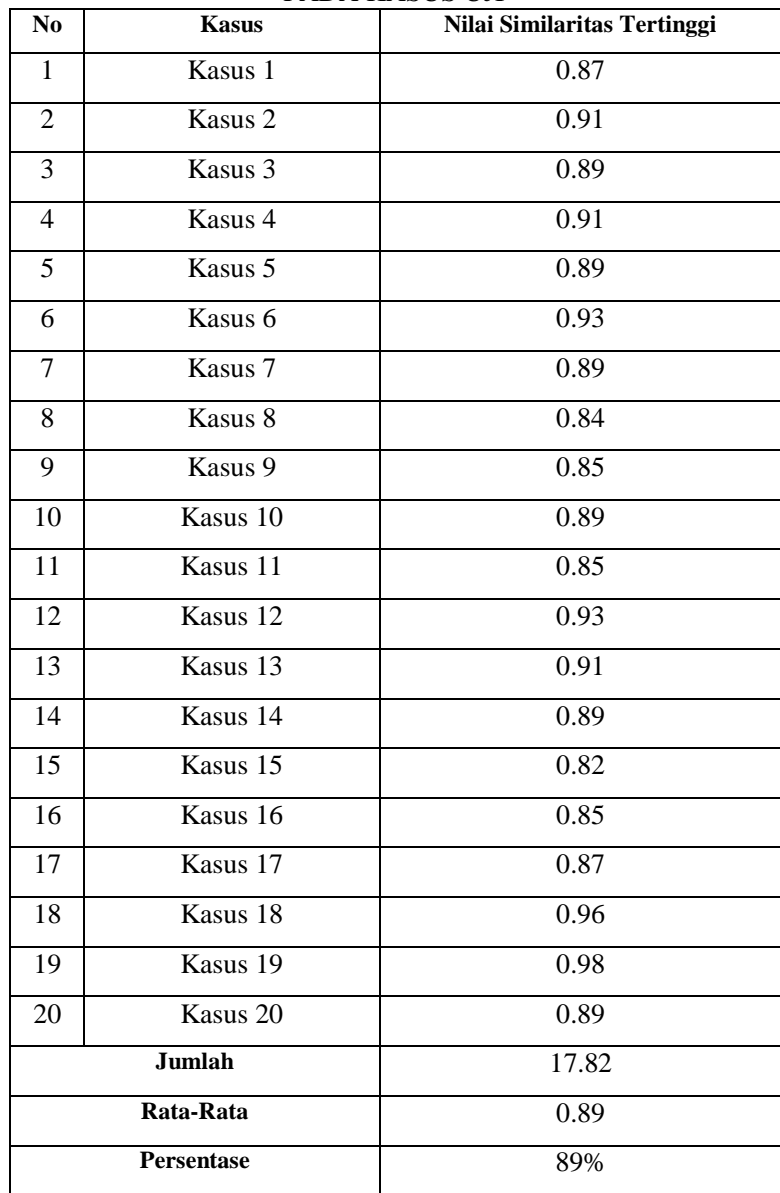

2. Pengujian Kuesioner

Pengujian kuesioner berisi 10 pertanyaan dan dibagikan kepada 30 responden. Responden akan mencoba aplikasi untuk dapat mengetahui kapabalitas dan kelancaran jalannya aplikasi itu sendiri. Berikut merupakan salah satu contoh perhitungan hasil kuisioner berdasarkan aspek rekayasa perangkat lunak:

TABEL III

HASIL KUESIONER ASPEK REKAYASA PERANGKAT LUNAK

\begin{tabular}{|c|c|c|c|c|c|c|c|}
\hline \multirow[b]{2}{*}{ No } & \multirow{2}{*}{$\begin{array}{l}\text { Aspek Rekayasa } \\
\text { Perangkat Lunak }\end{array}$} & \multicolumn{5}{|c|}{ Tanggapan } & \multirow[b]{2}{*}{ Total } \\
\hline & & 1 & 2 & 3 & 4 & 5 & \\
\hline 1 & $\begin{array}{l}\text { Kemudahan } \\
\text { menjalankan } \\
\text { aplikasi }\end{array}$ & 0 & $\overline{0}$ & 4 & 11 & 15 & 30 \\
\hline 2 & $\begin{array}{l}\text { Kelancaran } \\
\text { menjalankan } \\
\text { aplikasi }\end{array}$ & 0 & $\overline{0}$ & 1 & 14 & 15 & 30 \\
\hline 3 & $\begin{array}{l}\text { Kenyamanan dalam } \\
\text { menggunakan } \\
\text { aplikasi secara } \\
\text { keseluruhan }\end{array}$ & 0 & 0 & 0 & 12 & 18 & 30 \\
\hline \multicolumn{2}{|c|}{ Jumlah } & 0 & 0 & 5 & 37 & 48 & 90 \\
\hline \multicolumn{2}{|c|}{ Persentase (\%) } & 0 & 0 & 5,5 & 41,1 & 53,3 & 100 \\
\hline
\end{tabular}

Ket : 1 = Sangat Buruk $2=$ Buruk $3=$ Cukup Baik

$$
4=\text { Baik } \quad 5=\text { Sangat Baik }
$$


Secara keseluruhan, sebagian besar responden menilai aplikasi Sangat Baik dengan jumlah tanggapan Sangat Baik 48 dan memiliki persentase 53,3\%. Hal ini menunjukkan bahwa sebagian besar responden telah menanggapi aspek rekayasa perangkat lunak pada sistem Sangat Baik.

Berikut adalah Hasil Kuesioner:

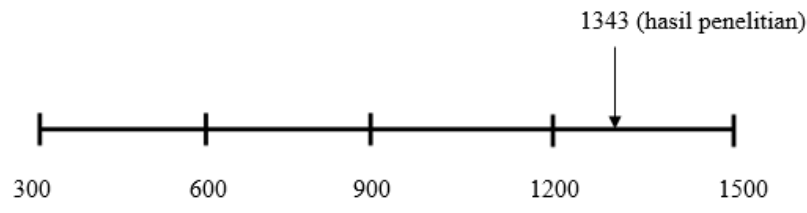

- $1200<$ skor < 1500, artinya program dinilai berhasil.

- $900<$ skor < 1200, artinya program dinilai cukup berhasil.

- $600<$ skor $<900$, artinya program dinilai kurang berhasil.

- $300<$ skor $<600$, artinya program dinilai tidak berhasil.

Gambar tersebut menunjukkan bahwa hasil penelitian berada di antara skor 1200 - 1500 yang artinya, hasil kuisioner menandakan responden menilai aplikasi sangat positif dan dinilai berhasil.

\section{Analisis Hasil}

Analisis hasil pengujian Aplikasi Pemilihan Resep Masakan dapat disimpulkan sebagai berikut:

1. Hasil pengujian tahapan proses Case Based Reasoning menunjukkan bahwa sistem ini dapat melakukan tahapan $4 \mathrm{R}$ pada CBR. Tahapan retrieve (menelusuri dan mendapatkan kasus-kasus dalam basis kasus yang mirip dengan kasus baru), reuse (menggunakan kembali kasus-kasus yang ada dan dicoba untuk menyelesaikan suatu permasalahan baru), revise (mengubah dan menyesuaikan output yang ditawarkan jika diperlukan), dan retain (proses penyimpanan data kasus baru ke basis kasus).

2. Hasil pengujian Metode Simple Matching Coefficient (SMC), menunjukkan bahwa berdasarkan hasil perhitungan persentase rata-rata nilai similaritas tertinggi, didapat nilai sebesar $89 \%$ yang digunakan untuk mengetahui keberhasilan sistem. Nilai tersebut diperoleh karena kasus uji memiliki banyak kesamaan dengan bahan bumbu yang terdapat pada basis kasus, sehingga sistem memberikan rekomendasi masakan dengan nilai similaritas tinggi yang mendekati nilai 1 .

3. Berdasarkan hasil kuesioner menunjukkan bahwa sistem dinilai sangat baik berdasarkan aspek rekayasa perangkat lunak dengan persentase 53,3\%.

4. Berdasarkan hasil kuesioner menunjukkan bahwa sistem dinilai baik berdasarkan aspek fungsionalitas dengan persentase $48,3 \%$.
5. Berdasarkan hasil kuesioner menunjukkan bahwa sistem dinilai sangat baik berdasarkan aspek komunikasi visual dengan persentase 53,3\%.

6. Berdasarkan hasil perhitungan dengan menggunakan metode Likert Summated Rating (LSR), didapatkan hasil penelitian diangka 1343 dari 1500 yang menunjukkan bahwa hasil kuisioner responden menilai aplikasi sangat positif dan dinilai berhasil.

\section{KESIMPULAN}

Berdasarkan hasil analisis dan pengujian pada aplikasi pemilihan resep masakan berdasarkan ketersediaan bahan masakan dengan metode Simple Matching Coefficient (SMC), dapat disimpulkan bahwa:

1. Sistem yang dibuat dapat melakukan proses $4 \mathrm{R}$ (retrieve, reuse, revise, retain) pada Case Based Reasoning (CBR). Tahapan retrieve (menelusuri dan mendapatkan kasus-kasus dalam basis kasus yang mirip dengan kasus baru), reuse (menggunakan kembali kasus-kasus yang ada dan dicoba untuk menyelesaikan suatu permasalahan baru), revise (mengubah dan menyesuaikan output yang ditawarkan jika diperlukan), dan retain (proses penyimpanan data kasus baru ke basis kasus).

2. Berdasarkan hasil pengujian Metode Simple Matching Coefficient (SMC) dengan menggunakan 20 kasus uji, menunjukkan bahwa hasil perhitungan persentase ratarata nilai similaritas tertinggi didapat nilai sebesar $89 \%$ sehingga sistem ini dapat memberikan rekomendasi resep masakan terbaik.

3. Sistem Case Based Reasoning (CBR) dengan perhitungan similaritas menggunakan metode Simple Matching Coefficient (SMC) yang dibangun pada aplikasi dapat menentukan rekomendasi resep masakan.

4. Berdasarkan pengujian kuesioner dengan metode Likert's Summated Rating (LSR), didapatkan skor sebesar 1343 dari 1500 yang artinya, hasil pengujian kuesioner menandakan responden menilai aplikasi sangat positif dan dinilai berhasil.

\section{REFERENSI}

[1] Sudiara, Bagus Putu. 2001. Pedoman Pusat Pendidikan dan Latihan Pariwisata. Bali : Dhyana Pura.

[2] Fitriyani, Rati. 2012, November 1. Pengertian Resep Masakan. Mei 08, 2018

http://ratifitriyani.student.esaunggul.ac.id/2012/11/01/pengertianresep-masakan-2/

[3] Watson, Ian. 1997. Applying Case-Based Reasoning: Techniques for Enterprise Systems. San Franscisco, California : Morgan Kaufmann Publisher Inc.

[4] Tan, P.N. M. Steinbach and V. Kumar. 2005. Introduction to Data Mining, Addison Wesley.

[5] Salsabella, Amira. 2014. Sistem Pendukung Keputusan Penentuan Resep Masakan Berdasarkan Ketersediaan Bahan Makanan Menggunakan Metode Simple Additive Weighting (SAW) Berbasis Web. Pontianak: Universitas Tanjungpura. 
[6] Tursina. 2014. Case Based Reasoning Untuk Menentukan Daerah Berpotensi Demam Berdarah (Studi Kasus Kota Pontianak). Pontianak: Universitas Tanjungpura

[7] Rani, Lia Atika. 2016. Penerapan Metode Case Based Reasoning Pada Pengembangan Aplikasi "Recipe Recommendation" Berbasis Android. Bandar Lampung: Universitas Lampung.

[8] Faizal, Edi. 2014. Case Based Reasoning Diagnosis Penyakit Cardiovascular Dengan Metode Simple Matching Coefficient Similarity. Yogyakarta: STMIK El-Rahma Yogyakarta.

[9] Annisa. 2017. Diagnosis Kerusakan Komputer Menggunakan Metode Similarity Jaccard Coefficient. Pontianak: Universitas Tanjungpura.

[10] Athloff, K, D. 2001. Case Based Reasoning, Handbook of Software Engineering \& Knowledge Engineering (ed. S.K. Chang). Singapore: World Scientific
[11] Aamodt A. dan Plaza E., 1994. Case-based Reasoning : foundation issues, methodological variation and System approach AI Communication, Vol. 7(1), pp. 39-59.

[12] Kursini and Hartati, S. 2011. Penggunaan Penalaran Berbasis Kasus Untuk Membangun Basis Pengetahuan Dalam Sistem Diagnosa Penyakit.

http://dosen.amikom.ac.id/downloads/artikel/full_paper_sriti_kusr ini.pdf.

[13] Ramayanda. 2014. Rancang Bangun Aplikasi Konseling HIV/AIDS Berbasis Web Dengan Penalaran Case Based. Pontianak: Universitas Tanjungpura

[14] Pal, Sankar K., dan Simon C. K. Shiu. 2004. Foundation of Soft Case-Based Reasoning. New Jersey: John Wiley \& Sons, Inc.

Sugiyono. 2010. Metode Penelitian Pendidikan Pendekatan Kuantitatif, kualitatif, dan R\&D. Bandung: Alfabeta.

[15] Sugiyono. 2010. Metode Penelitian Pendidikan Pendekatan Kuantitatif, kualitatif, dan R\&D. Bandung: Alfabeta 